fatness as a cause of sterility, but whether this is effective through the action of fat in absorbing oestrogens or blocking the production of progesterone is not known. It should be remarked, however, that over-fatness may be the result, as well as the cause, of infertility.

\title{
REFERENCES
}

Asdell, S. A., Bogart, R. \& Sperling, G. (194I). Mem. Cornell agric Exp. Sta. no. 238.

Bodenheimer, F. S. \& Sulman, F. (r946). Ecology, 27, 235.

Bonsma, J. C. (1948). Personal communication.

Dunlop, G. (1944). Proc. Brit. Soc. Anim. Prod. and Meet., p. 57.

Du Toit, P. J. \& Bisschop, J. H. R. (1929). Rep. vet. Res. S. Afr. 15, 1059.

Eckles, C. H. (1920). Res. Bull. Mo. agric. Exp. Sta. no. 36.

Evans, H. M. \& Bishop, K. S. (1923). Amer. F. Physiol. 63, 396.

Evans, H. M., Meyer, K. \& Simpson, M. E. (1933). Mem. Univ. Calif. 2, 423.

Foa, C. (1901). Arch. ital. Biol. 35, 364.

Gorrie, C. J. R. (1946). Stock and Land, Melbourne, 3 July, p. 3.

Hammond, J. (1925). Reproduction in the Rabbit. Edinburgh: Oliver and Boyd.

Hammond, J. (1943). Proc. Nutr. Soc. 2, 8.

Heape, W. (1931). Emigration, Migration and Nomadism, Cambridge: W. Heffer and Sons Ltd.

Kelley, R. B. (1937). Bull. Coun. Sci. industr. Res. Aust. no. I I 2.

Laptev, M. A. (1940). In Feeding of Farm Animals and Fodder Production, p. 67. Moscow: Lenin Academy of Agricultural Sciences.

Larsen, L. H. \& Sørensen, E. (1944). Beretn. Forsogslab., Kbh., no. 209.

Loeb, L. (1917). Biol. Bull. Wood's Hole, 32, 187.

McKenzie, F. F. (1928). Res. Bull. Mo. agric. Exp. Sta. no. I 8.

Madsen, L. L., Hall, S. R. \& Converse, H. T. (1942). F. Nutrit. 24, 15.

Marrian, G. F. \& Parkes, A. S. (1929). Proc. roy. Soc. B, I05, 248.

Marshall, F. H. A. (1908). Trans. Highl. agric. Soc. Scot. 20, I39.

Miller, R. F., Hart, G. H. \& Cole, H. H. (1942). Bull. Calif. agric. Exp. Sta. no. 672.

Prentice, J. H., Basket, R. G. \& Robertson, G. S. (1930). World's Poult. Congr. iv. London, p. 224.

Reineke, E. P. (1946). In The Problem of Fertility [E. T. Engle, editor]. Princeton: University Press.

Roux, L. L. (1936). Onderstepoort F. vet. Sci. 6, 465.

Smirnov-Ougryumov, V. (1937). Probl. Anim. Prod., Moscow, no. 3, p. 43.

Smith, P. E. \& Engle, E. T. (1927). Amer. F. Anat. 40, 159.

Wallace, L. R. (1948). F. agric. Sci. 38, 243.

Zondek, B. \& Aschheim, S. (1927). Arch. Gynaek, r3o, I.

\section{Spermatogenesis and Nutrition}

\section{By Arthur Walton, School of Agriculture, Cambridge}

Before one can appreciate the significance of experimental data on the effects of nutrition on separate organs of the body it is necessary to have a clear perspective of the metabolic processes involved and of their magnitude in relation to the general economy of the body as a whole. This is perhaps more necessary with the testis than with other organs, because, for psychological reasons, this organ may be accorded an importance in the mind of man far in excess of its actual physiological significance. In addition, one should have an understanding of the methods used in measurement of sperm production and testis activity and know how these measurements are related to the physiological functions which they are supposed to assess. In this paper I deal primarily with these aspects and not with the experimental or clinical data, because I think that they are fundamental and often neglected. 
The testis is a relatively small organ. Between species there is considerable variation in the ratio of testis weight to mature body-weight. The following figures are very approximate: ram I: I80; boar, I:250; bull I:2500; stallion I:3000. The smaller animals have relatively larger testes, but the relationship is not constant. For example, the ram has relatively larger testes than animals of about the same size.

The secretory output of the gland is also relatively small compared with, say, the output of the salivary glands, gastric and intestinal mucosas, sweat glands and active mammary glands. The individual variation in output is very great and depends almost entirely upon the opportunity for coitus, masturbation, or spontaneous emissions, and a reliable figure for total sexual output is extremely difficult to obtain. In man, Kinsey, Pomeroy \& Martin (1948) found a mean of 2.74 orgasms per week for males between adolescence and 85 years, but the variation was from nought to twenty-nine. As the average volume of the ejaculate is $4 \mathrm{ml}$. for emissions of moderate frequency, and perhaps about $2 \mathrm{ml}$. for very frequent emissions, this makes a total weekly output of on the average $10 \mathrm{ml}$. and for the extreme cases $60 \mathrm{ml}$. Of this total ejaculate only a small fraction, about one-tenth, comes from the testes. The bulk of the fluid comes from the accessory glands. Figures for animals are difficult to calculate. A bull in my laboratory performed eight ejaculations in $63 \mathrm{~min}$., and produced a total of $29 \mathrm{ml}$. of semen of which about $6 \mathrm{ml}$. came from the testes. This performance could not be kept up. Sexual libido falls rapidly with frequent coitus, and the bull towards the end of the experiment showed diminished libido. Kirillov (1935), with four matings a day for 7 weeks, obtained $43.4 \mathrm{ml}$./week. The average volume fell from a normal ejaculation of about $4 \mathrm{ml}$. to $1.55 \mathrm{ml}$. and libido diminished, so it is probable that maximum output was obtained by this method. The output of secretion from the testes in this experiment would be about $8 \mathrm{ml}$./week.

Higher outputs might be obtained with natural matings and with animals kept under optimum conditions of management, but it seems unlikely that sperm production from the testis would exceed ro ml./week. These experimental rates greatly exceed the normal output of bulls at artificial insemination centres, where six ejaculations per week is a high figure and the total weekly output from the testes must be in the region of $3 \mathrm{ml}$. With small animals, the output in relation to body size is considerably greater. With the rabbit Edwards (1939) collected six ejaculates per week over a long period. The average volume was $2.4 \mathrm{ml}$., making a total weekly output of $14.4 \mathrm{ml}$. of which about $0.7 \mathrm{ml}$. would come from the testes.

The output has been discussed in terms of volume. Since, however, about $90 \%$ of semen consists of water, the total weekly output of dry matter and of its chemical components is to be measured not even in grams, but in milligrams.

The greatest nutritional demand for sexual activity comes from the requirements of the accessory glands, and in animals which secrete large volumes of accessory fluid this might be appreciable. According to Davidson (1948) a boar may exceptionally serve a sow nearly every day for about I month. The volume of semen produced at each service in the boar varies with the number of ejaculations. If it is assumed that a boar used frequently produces an ejaculate of $150 \mathrm{ml}$., and that five services a week is the allowance, a total weekly output of $750 \mathrm{ml}$. will be obtained. As far as the testis is 
concerned, however, the total output would be about $2 \%$ of the semen, i.e. $14 \mathrm{ml}$. or $2 \cdot 8$ g. dry matter.

An appreciable increase in calorie requirement may come from the physical exertion of mating, but with animals regularly exercised, this would be a small proportion of the total requirement. In man the effect of the physical exertion of copulation may be exaggerated owing to the intense nervous tensions aroused and the subsequent lassitude. This may be experienced by animals also. There is no evidence that this nervous tension does more than raise temporarily the metabolic rate of the body as a whole.

Although the nutritional requirements, considered in terms of output, are small, output does not give a complete measure of the metabolic activity of the testis. Spermatozoa are continuously produced in the testis whether copulation takes place or not. According to Simeone \& Young (I93I) the spermatozoa that are not ejaculated are resorbed in the lower part of the vas deferens. According to some authors there may also be a loss through the urethral passage in the urine, though this is denied by Simeone \& Young. Measurement of the total metabolic turnover of the testis would therefore have to include not only the ejaculated spermatozoa but also those resorbed. We have no method of measuring the amount resorbed directly, but can arrive at some estimate of its magnitude from the following considerations. As the frequency of ejaculation increases there is a fall in the output of spermatozoa per ejaculate but a rise in the total output per week until a maximum is reached. It seems reasonable to assume that at these higher rates of ejaculations spermatozoa are being removed as rapidly as they are formed, that the storage period is reduced to a minimum, and that few if any spermatozoa are resorbed. At the higher rates of ejaculation from which we have calculated our outputs, the resorption of spermatozoa is therefore likely to be very small. At lower rates of ejaculation, two possibilities arise, either the resorption increases in proportion to the number of non-ejaculated spermatozoa left in the tract, or testis activity is reduced and fewer spermatozoa produced (see Chang, I945). In the latter case our estimate of total production, based on frequent ejaculations, will be higher than normal, not less.

The view is often expressed that, although the nutritional demand based upon output is small, the demand is for exceptional substances which may be in short supply in the body. The biological and biochemical evidence, however, does not support this view. The main bulk of the spermatozoon is formed of the head, of which the most important and highly organized fraction is the nucleus. Genetic argument leads to the conclusion that the nucleus contains exactly one-half of the gene complement of the somatic cells throughout the body, and that the genes are not different in chemical composition from those of the somatic tissues. Furthermore, in meiosis, cell division occurs twice, but replication of nuclear material once, so that nuclear synthesis in spermatogenesis is less than in somatic cell divisions. Furthermore, once formed, the nucleus of the spermatid enters a resting condition, and the cell neither grows nor divides. There is no further nuclear synthesis. Biochemical analysis does not reveal the presence of exceptional substances. The data have been recently reviewed by Mann (1949) and need not be quoted in detail. The head of the spermatozoon consists largely of histone or protamine, which are simple proteins, and of ribonucleic 
acid, which is a component of all cell nuclei. Other constituents must be of very small magnitude.

The tail of the spermatozoon is very small in proportion to the head, and is the organ of metabolic activity and locomotion after ejaculation, but it is probably inactive or quiescent in the male tract. The metabolism of the mammalian spermatozoon has been much studied recently (see Mann, I949). The respiratory system is complex, comprising a large number of enzymes, coenzymes and intermediary products, but the system as a whole is remarkably similar to that of muscle.

The spermatozoon is a very highly differentiated cell with an elongated form, a complex internal structure, and an equally complex structural surface as revealed by electron microscopy (Bretschneider \& van Iterson, 1947). If we regard the simple spherical cell with spherical nucleus as the cell form with the least free energy, the formation of a spermatozoon from the spermatid must involve a large decrease of entropy locally, and if the thermodynamic efficiency of the process of biological synthesis is not high there might be a correspondingly large increase in entropy in the system as a whole. One might expect therefore a fairly high metabolic rate to accompany spermatogenesis and spermateleosis, but manometric measurements of testis tissue metabolism do not reveal exceptional differences when compared with those of other tissues (Krebs, 1933). Moreover, the testis functions normally at a temperature $2-3^{\circ}$ below that of the body, so that the metabolic rates may in fact be rather less than that of other tissues.

One ought perhaps to mention here the hormonal function of the testis, i.e. the synthesis of testosterone. The formation of this substance in large quantity might exert a demand on its precursors, but replacement therapy following castration, with testosterone pellets indicates that synthesis is to be measured in $\mathrm{mg}$./day and not in large quantities.

To summarize it may be said that, in terms of output, the testis exerts no special demands upon the general economy of the body and that no exceptional substances are formed. We may expect from this that, provided the animal receives a nutrition adequate to maintain bodily health, the needs of the testes will be adequately met.

\section{REFERENCES}

Bretschneider, L. H. \& Iterson, W. van (1947). Proc. Acad. Sci. Amst. 50, 88.

Chang, M. C. (1945). F. agric. Sci. 35, 243.

Davidson, H. R. (1948). The Production and Marketing of Pigs. London: Longmans, Green and Co.

Edwards, J. (1939). Proc. roy. Soc. B, 128, 407.

Kinsey, A. C., Pomeroy, W. B. \& Martin, C. E. (1948). Sexual Behaviour in the Human Male. Philadelphia: W. B. Saunders Company.

Kirillov, V. S. (1935). Anim. Breed. Abstr. 3, 255.

Krebs, H. A. (1933). Oppenheimer's Handbuch der Biochemie. Ergänzungswerk I-III, and ed., p. 863.

Mann, T. (1949). Advances Enzymol. 9 (In the Press).

Simeone, F. A. \& Young, W. C. (1931). 7. exp. Biol. 8, 163. 